\title{
Ireland: Celtic Tiger in Austerity-Explaining Irish Path Dependency
}

\section{Mary P. Murphy}

To cite this article: Mary P. Murphy (2014) Ireland: Celtic Tiger in Austerity-Explaining Irish Path Dependency, Journal of Contemporary European Studies, 22:2, 132-142, DOI: 10.1080/14782804.2014.902367

To link to this article: https://doi.org/10.1080/14782804.2014.902367

曲 Published online: 08 Jul 2014.

Submit your article to this journal

Џll Article views: 446

Q View related articles $\sqsubset$

View Crossmark data \lceil

4 Citing articles: 5 View citing articles 


\title{
Ireland: Celtic Tiger in Austerity- Explaining Irish Path Dependency
}

\author{
MARY P. MURPHY* \\ NUI Maynooth, Ireland
}

\begin{abstract}
Previous Irish crises have proved to be path shaping. The paper argues many features of Irish policy responses to crisis including low taxation, user charges, privatisation, deregulation and more conditional welfare are consistent and at times intensify the liberal deregulated low tax model that characterised the pre-crisis Celtic Tiger model. It makes the case that the differential impacts on Irish citizens were significant enough in scale and impact to occasion a critical juncture and significant shifts in political cleavage or a double movement and asks why there has been no path shaping critical juncture. This article explores why Irish path dependence is so strong in this crisis and utilises Hay's (2004) analytical framework and a mixed method approach to explain the gradient and orientation of change as an outcome of the relationship between institutions, interests and ideas. It concludes an elite political coalition reshaped institutions and sustained a strong narrative to maintain path dependency.
\end{abstract}

KEY WORDS: Ireland, austerity, interests, ideas, institutions

\section{Introduction}

Previous Irish economic crises have proved to be path shaping as regards Ireland's political economy: responses to the 1950s crisis shaped a new economic regime in the Programme for Economic Expansion which reoriented and opened the economy towards international investment (Ireland 1958). The response to the 1980s crisis shaped the 1987 Programme for National Recovery (Ireland 1987) which laid the foundations of the Celtic Tiger model of light regulation, low taxation and foreign direct investment. One might expect both the scale and impact of the last six years of crisis in the Irish political economy to occasion a path shaping moment. Wickham $(2013,1)$ argues such shifts have not appeared and that Ireland is 'surviving without changing'. The overall character of policy and institutions remains constant. If he is correct we might ask why this crisis has not been path shaping? This article explores why path dependence, in the sense of persistence of the deregulated, low taxation, foreign direct investment model, is so strong in this crisis. Framed against theoretical debates concerning regime change and stasis in comparative political economy, the paper speaks to the comparative institutional literature. It explains the strength of Irish path dependence by utilising Hay's (2004) analytical framework to explain the gradient and orientation of change as an outcome of the relationship between institutions, interests

*Correspondence Address: Sociology, Auxilia, Dept Sociology, NUI Maynooth, Co. Kildare, Ireland. Email: mary.p.murphy@nuim.ie

(C) 2014 Taylor \& Francis 
and ideas. The article concludes that an elite political coalition is reshaping institutions and sustaining a strong narrative to maintain and intensify path dependency.

The paper first introduces an analytical framework to explain continuity and change. It then briefly outlines Irish policy responses to the Great Recession and argues that many features of these are consistent with a liberal deregulated low tax model that characterised the pre-crisis Celtic Tiger model. We make the case that the differential impacts on Irish citizens were significant enough to occasion a critical juncture and new political coalitions. The puzzle is why such strong path dependency has occurred when we might have expected pressure for change. We use a mixed method approach, including empirical analysis, policy mapping and discourse analysis to explain this continuity. The data are largely collated from secondary sources but some primary data concerning crisis narratives are gathered to analyse ideational debate. The organising theme for the analysis is the interaction of three variables: ideas; interests; and institutions. We first map ideational debate, then key institutional shifts and finally interest formation. We conclude by isolating the interaction of ideas, interests and institutions.

\section{Ideas, Institutions and Interests}

Path dependence means that institutions are self-reinforcing, that policy, once developed in a particular direction, is locked into that policy choice and is difficult to change (Pierson 1998). Irish political economy has historically unfolded as a series of regime changes in moments of path shaping punctuated equilibrium. Responses to the 1950s crisis clearly shaped a new open economic regime in the Programme for Economic Expansion (Ireland 1958); taxation and industrial policy were oriented towards foreign direct investment. The response to the 1980s crisis also reshaped and reoriented policy to intensify dependence on multinationals and embed the low tax regime which lay the foundations of the Celtic Tiger (Ireland 1987). The scale of change can be understood as paradigmatic even though the previous regime had been liberal in nature (Hall 1993). ${ }^{1}$

From a Polanyian (2001) 'double movement' perspective, significant social dislocation brings about spontaneous moves by society to protect itself. Following this logic we might expect new political coalitions to emerge during the crisis. We might expect, as in previous critical junctures, the Great Recession to create a path shaping momentum. New institutional scholarship (Hall and Taylor 1996) comprises sociological (culture), historical (institutions), rational (material interests) and, following Hay (2004), constructivist (ideational) approaches to explain regime change or stasis. Both Cox (1995) and Hay (2004) avoid privileging one of these factors over others but use a three-dimensional framework to understand the process of change or stasis as the interaction of ideas, institutions and interests. Adopting this organisational framework our central question is how ideas, institutions and actors interacted throughout the crisis and whether they maintained or intensified policy continuity or created a path shaping moment.

\section{Economic Volatility, Crisis and Stasis}

\section{Policy Responses}

Following the 2007 collapse of US bank Lehman Brothers it became evident that Irish banks were exposed to systematic risk. In September 2008 the Irish state decided to 
bail out all domestic banks and to establish a National Asset Management Agency (NAMA) to manage property related bad debts or toxic assets. It thus transferred public resources directly to private banks and bank shareholders and in doing so socialised the risk attached to private profit making (O'Toole 2009). By doing so it added greatly to the state's debt burden. A pre-crisis Commission on Taxation which reported in September 2009 was required in its terms of reference to recommend revenue-neutral tax reform proposals thus ensuring Ireland remains a low-tax economy. This included retaining the present low corporate tax regime of $12.5 \%$, a policy that anchors foreign direct investment at the centre of the Irish development model. Early crisis budgets (with the exception of carbon taxes) did not proceed towards widening the tax base or introducing progressive tax reform options; for example, property tax was not introduced until the 2013 budget. The combination of bailing out banks and choosing not to pursue tax related revenue gathering policy options meant reliance on public expenditure cuts to manage the public deficit. Public debate about Budget 2010 was framed in the context of a government initiated Report of the Special Group on Public Service Numbers and Expenditure Programmes (McCarthy 2009) which reflected an underlying ideology that prized low social expenditure and served the purpose of preparing the public and electorate for cuts in public expenditure.

Socialisation of Irish banks' debts increased Irish sovereign debt to unsustainable levels occasioning the November 2010 loss of sovereignty to the Troika of the European Commission, European Central Bank and the International Monetary Fund whose bailout package included a Memo of Understanding (MOU) to underpin the loans. The plan (largely consistent with a contemporaneous domestic government plan), was a blueprint for intensification of the liberalisation of the economy. It committed to removing remaining restrictions on trade and competition and to open up sheltered areas of the legal, medical and pharmacy sectors to greater competition (Hardiman and Regan 2012). Like structural adjustment programmes in Latin America, Africa and Asia it required a continued liberalisation of Ireland's political economy and increased marketisation of previously protected public spheres including water charging and privatisation of state owned electricity and gas companies. Labour reforms required reform of the benefits system to create greater incentives to take up employment and tighten eligibility and means-tested criteria (Hardiman and Regan 2012, 12).

From the late 1980s onwards 'a low-tax, service-poor equilibrium began to become embedded in Irish political economy as the engine of growth and employment creation' (Dellepiane and Hardiman 2012, 11). While sometimes considered a hybrid, 'Ireland is strongly integrated into the Anglo-American business environment; it fits quite well into Hall and Soskice's model of a liberal market economy' (Dellepiane and Hardiman 2012, 23). Early responses to the crisis were characterised by either policy continuity or intensification of this existing neoliberal model of political economy. The overall character of policy and institutions remains a broadly liberal economic model and some changes including privatisation of public services, user charges, dualisation in the labour market, sanctions driven activation regime, represent an intensification of the neoliberal model. While there have been tax increases (Callan et al. 2013) Ireland remains a low tax regime and now has less investment in health, education, housing, social, care and local and community development services. 


\section{Impacts}

Since the onset of the crisis Ireland went from very high rates of growth to deep negative rates and after some recovery, stagnation. Growth in 2007 was at 5.4\% of GDP, plunging to $-5.5 \%$ in 2009 , to recover somewhat to $1.6 \%$ in 2011 (Caritas 2012, 23). Meanwhile the gross debt to GDP ratio ballooned from $24.8 \%$ to $106.4 \%$ between 2007 and 2011, with the government deficit going from $0.1 \%$ to $13.4 \%$ of GDP in the same period. This section discusses the impact of policy adjustments and market changes and argues the scale of impact was significant enough to trigger a path shaping critical juncture.

Early crisis fiscal consolidation was progressive in its overall distributional impact while later Budgets of 2012 and 2013 were regressive. The combined distributional effect of changes in the tax/benefit systems between 2009 and 2014 has reduced the incomes of the richest $10 \%$ of the population by $15.5 \%$, the poorest $10 \%$ by $12.5 \%$ and the remaining $80 \%$ by between $11 \%$ and $12 \%$ (Callan et al. 2013). In early budgets the adult social welfare payments were reduced by $8 \%$ while social welfare pensions remain protected. Over the crisis social welfare was more than halved for those under 25 and Child Benefit was reduced from $€ 166$ p.m. in 2010 to $€ 130$ p.m. in 2013 (with additional cuts to the higher payments for the third + child). Along with young people, social welfare dependent single families with children fared worst of all, a point we return to later in the analysis. There has been no substantial analysis of cuts in services however they are likely to be regressive (Callan et al. 2013; Holland 2012).

Market impacts have been severe. Between 2007 and 2010 the numbers earning over $€ 100,000$ fell by almost $15 \%$, while the average income of those who were still earning over $€ 100,000$ fell by about $8 \%$ (FitzGerald 2014). Irish labour unit costs fell by $12.2 \%$ during the same period due to the imposition of wage cuts (especially in the public sector) and an increase of Irish labour productivity (Erne 2013). Average annual disposable income fell from $€ 24,380$ to $€ 21,440$ between 2008 and 2011 (CSO 2013). Unemployment rose from $6.4 \%$ in 2008 to nearly $15 \%$ in 2012 and dropped to $12.4 \%$ in early 2014 . Longterm unemployment (over one year) rose from half of those unemployed in 2010 to $60 \%$ in 2012 and dropped to 58.4\% in 2014 (with 60,000 unemployed for more than four years). Male underemployment (involuntary part-time work) doubled from 6\% in 2007 to $12 \%$ in 2011 and the numbers of households with very low work intensity rose from $14.2 \%$ to 22.9\% in the period from 2007 to 2011 (Watson and Maître 2013). Joblessness and scarring remain closely correlated with low education qualifications and a largely working class experience (Gonzalez Pandiella 2013).

The Central Statistics Office (CSO) (2013) shows poverty and inequality rising but still below pre-Celtic Tiger levels. Consistent poverty rose from $4.2 \%$ in 2008 to $6.9 \%$ in 2011 and relative income poverty rose from $14.1 \%$ to $14.9 \%$ over the same period. Watson and Maître (2013) find high levels of efficacy in Irish social transfers. Despite cuts Irish welfare payments remain relatively effective in cushioning people from the worst effects of rising unemployment and falling incomes. Social transfers reduced the pre-transfer poverty rate by $53 \%$ in 2004 and $71 \%$ in 2011 . Despite such resilience deprivation rates still rose from 13.8 to $24.5 \%$ between 2008 and 2011 and rose up to $58 \%$ for lone parents (CSO 2013). Ten per cent of the population are estimated to experience food poverty and there is growing use of soup-kitchen style food distribution. Over six years the cumulative impact of austerity is deepening and the pressure of new charges (property tax, water charges, increased utilities and transport and housing costs) becomes more difficult to 
sustain. Families with children are particularly hard pressed, especially those in vulnerable housing situations. Barry and Conroy (2013) show women are more likely to be employed in the public sector, reply on public sector services and be in receipt of a social welfare payment, consequently reductions in social expenditure have had gendered impacts. Generational consequences of the crisis are particularly acute. Emigration, unemployment, mortgage arrears and negative equity affect younger households more than older households and there is every likelihood of significant scarring for what has become known as 'a lost generation'.

The question is how and why this liberal path dependence was intensified when the scale and impact of the market changes and policy adjustments might suggest sufficient pressure to create new political coalitions and potentially path shaping conditions?

\section{Ideational Politics of Austerity}

Hall (1993) stresses the importance of discourse arguing it provides language for talking about particular topics and that it rules in certain ways of talking and rules out other alternatives. Blyth (2001) draws attention to the role of business members in the ideational construction of discourse while Corcoran (2004) distinguishes between political preferences of media editors and journalists. We show that an elite coalition of business and the government was consistently supported by an elite media to maintain and strengthen the neoliberal trajectory of the Irish political economy. Here we isolate three austerity related discourses: reform, transformative and revolutionary narratives, examine how these narratives were reflected in mainstream media and review the successful framing activities of the dominant political group.

Reform narratives reflect what many see as realistic assessments of the status quo where Ireland with a troubled tax base, declining revenue and increasing borrowing costs faced real problems to survive fiscally. These narratives accept this reality and support fiscal consolidation but seek institutional reform to make the economy more competitive, efficient and entrepreneurial and politics less corrupt. Kirby and Murphy $(2011,217)$ outline a range of business or elite led narrative processes including New Ireland (an informal group of 17 high profile business men and ex-politicians) who focused on accountability and recapturing competitiveness in their 2011 A blueprint for Ireland's recovery. The McGill annual summer school (Mulholland 2010) and Dublin City Business Association (Coffey 2011) championed political reforms alongside renewed competitiveness. Funded by the state, Your Country, Your Call (2010) led by Dr Martin McAleese (husband of the then President) called for 'entrepreneurial citizenship' which Abowitz and Hannish (2006) argue naturalises competition and reinforces neoliberalism. The Irish Times led series Renewing the Republic (2010) focused on renewal of the political state compatible with neoliberal values as did the 2011 'We the Citizen', an academic led action research project. Collectively these initiatives reinforced a 'business as usual' mantra and contributed to the maintenance of previous state-market relations.

Transformative narratives engage in explicit exercises to frame alternatives to neoliberalism and focus on areas where government may be able to exercise some discretion in fiscal adjustment restraint (ICTU 2008). Claiming our Future (COF) for example framed a narrative to advance an alternative to a neoliberal Ireland. 'Plan B', a 2012/13 campaign to popularise a macroeconomic alternative to austerity, focused on increased investment, higher taxation and maintenance of key public spending initiatives 
(Murphy 2013). This initiative is consistent with a number of key anti-neoliberal thinktanks, including TASC a think-tank for action on social change; the religious based Social Justice Ireland; the trade union funded Nevin Economic Research Institute; various trade unions and the Irish Congress of Trade Unions. Despite successful mobilisation and coordination of key interests, they have failed to sufficiently mobilise public support. This may in part be due to tactical failures and unequal access to media and resources but also because of fears among potential allies that the state might inhibit and suppress mobilisation or advocacy work (Harvey 2013). It is also the case however that such views do not align with the more general configuration of Irish interests and preferences as visible in voting patterns and opinion polls (Kirby and Murphy 2011).

Revolutionary narratives engage with an anti-capitalist narrative. While some of these narratives led to substantial mobilisations none led to a lasting political coalition. These are evident in the Irish Occupy Movement which developed a broad anti-capitalist narrative without identifying specific alternatives. Other narratives mobilised around specific issues including a Debt Repudiation campaign led by the Communist Party of Ireland (CPI 2012) The most successful and largest mobilisation was the 2011-13 Campaign against Home and Water Taxes. ${ }^{2}$ While anti-capitalist in origin the campaign narrative was positioned ambiguously in relation to neoliberalism, capitalism and taxation, the broad anti-taxation narrative reflecting the compromises of wide-ranging coalitions united by their lowest common denominator.

While all three narratives are present in Irish political discourse the reform narrative is by far the most dominant in the media. Mercille (2013) analysed 431 editorials and opinion articles discussing fiscal consolidation between 2008 and 2012 in three leading Irish newspapers (Irish Times, Sunday Independent, Irish Independent). He found the majority of articles present reform narratives and that they favour fiscal consolidation, displaying a preference for spending cuts over tax increases. Others contest specific spending cuts but do not criticise fiscal consolidation. A minority oppose fiscal consolidation. These are mostly consistent with the transformative narrative and call for economic alternatives, such as Keynesian stimulus, which are consistent with capitalism. There is little media evidence of revolutionary narratives; this reflects the paucity of such narratives in Irish discourse but also that, as in the example above, tactics used to appeal to mainstream audiences narrowly frame issues and avoid the broader anti-capitalist narrative. While there are ideological cleavages within the three newspapers all are broadly favourable to fiscal consolidation. A more fiscally conservative ideology evident in Independent newspapers is consistent with Independent News and Media being owned and controlled by economic elites and driven by commercial factors. That the Irish Times is owned by the Irish Times Trust ensures some limited independence from commercial interests albeit that it is still dependent on advertising revenues and oriented towards the elite origin of board directors (Mercille 2013).

TASC (2010) identified a golden circle of Irish business and political elites, a small minority of whom appear exceptionally influential (Parry 1967, 13). The government, proactively and in alliance with indigenous business forces (IBEC, Chambers of Commerce) and an elite, commercially dominated media, has successfully framed crisis narratives. Holland $(2012,12)$ argues 'the case for curbing public spending commitments has acquired the status of received opinion among political, financial and media elites'. Transnational actors including global finance and foreign investment (for example American Chambers of Commerce) as well the European Union, OECD and IMF 
reinforced this narrative. Public sector and welfare recipients, and trade unions were 'unable to veto a strategy that was deemed to be essential to restoring both financial credibility and business confidence' (Dellepiane and Hardiman 2012, 23; Doherty 2011). In part they were actively hindered by government led narratives that pitted public sector workers against private sector workers and consistent narratives about social welfare fraud that set welfare claimants against citizens (often framed as tax payers).

\section{Institutional Reforms and Narrowing of Public Spheres}

We can differentiate states according to institutional characteristics that give rise to "veto points' (Tsebelis 2002, 209). Some political systems 'are more prone to crisis engendered institutional change', others are characterised by 'incremental reformism' Hay (2004, 205). The Irish electoral system combines with other veto points including a rigid constitution and bicameralism. Since the early 1980s critical juncture, coalition governments and social partnership provided additional veto points to orient Irish political culture and policy making in a direction that makes path dependence more likely. Power is traditionally centralised in the Irish political system and the Minister for Finance has wide autonomy (Kirby and Murphy 2011). While there have been some initiatives to strengthen parliamentary scrutiny, further centralisation of power has been a key institutional strategy of both crisis governments. Many key decisions and legislative changes have bypassed parliamentary processes and been enacted through emergency legislation (bank bailout 2008, Anglo Irish Bank nationalisation 2009, closure of Irish Bank Resolution Corporation 2013) or through the use of guillotine motions that shortcut scrutiny of legislative changes including social welfare and finance acts (Kirby and Murphy 2011; O’Toole 2009).

Troika institutional arrangements have further impacted and centralised the process of policy making: 'All budget decisions must be cleared with the Troika, fiscal performance is subject to quarterly reviews and Troika personnel are embedded in the core government departments' (Hardiman and Regan 2012, 9). Alongside the Troika new domestic institutions help maintain an ideology of fiscal consolidation. Various institutions including NAMA, a Commission on Taxation and a Special Group on Public Service Numbers and Expenditure Programmes coloured early responses to the crisis. The 2011 political coalition created the Irish Fiscal Advisory Council with a remit to assess independently, and comment publicly on, budgetary targets and objectives. This council tended to argue for even more fiscal consolidation. Within the cabinet, the 2011 coalition established a new ministry for Public Expenditure and Reform to drive fiscal consolidation and an elite all male Economic Management Council (EMC) comprised of the top four ministries of the government to consolidate fiscal consolidation at the centre of government.

Managing the crisis has been an elite-led process. National and local non-government organisations which might have joined or strengthened political coalitions constructing alternatives were closed down, experienced political exclusion or were curtailed by new funding regimes (Harvey 2013). Commenting on citizenship engagement, Holland (2012, 11) notes 'a clear lack of popular participation in both the design and implementation of crisis response measures'. There has been little use of poverty proofing processes or social impact analysis of Irish budgetary decisions and little meaningful engagement with instruments to monitor distributional impacts of decisions (EAPN 2013). The National Economic and Social Forum was an early casualty of state rationalisation. The Human 
Rights Commission and the Equality Authority were first downgraded and then slowly merged and the Combat Poverty Agency was integrated into the Department of Social Affairs (Holland 2012, 16). Even if the motivation was purely cost saving, these closures nonetheless weakened non-elite political coalitions. Pre-crisis civil society, including trade unions and social oriented NGOs had some influence on socio-economic policy through the Social Partnership arrangements (NESC 2009). This voluntary process ended rather abruptly once the crisis hit, a trend consistent with erosion of collective bargaining rights across Europe (Doherty 2011). Trade unions and non-government organisations found it difficult to find other sources of power and influence. The standing down of social partnership is also reflected in the lack of impact of various National Economic and Social Council comments about the crisis (NESC 2009). This lack of impact can be contrasted with the role the NESC played framing responses during the 1980s crisis (Ireland 1987; NESC 1987).

\section{Interests and Political Coalitions}

Partisan politics is a crucial factor determining variation in a government's responses to crisis (Huber and Stephens 2001). Given two political coalitions governed over the period in question we can examine whether or how partisan responses varied. The incumbent Fianna Fail (FF) and Green Party (GP) coalition responded to the early fiscal problems of collapsed revenues and upward pressure on public spending with two key initiatives, a new Special Expenditure Review and an already established Commission on Taxation. These two initiatives were consistent with a neoliberal path and created their own structural dynamics and path dependencies. This coalition also constructed the 2008 bank bailout, established the NAMA and negotiated the loan and the MOU with the Troika. While the MOU mirrored an existing government National Recovery Plan for 2011-14 it became the blueprint for managing the crisis.

In reality the MOU left some flexibility as to how government could achieve fiscal consolidation and room for partisan politics. Weymes $(2012,8)$ shows that in practice different programme states exercise different expenditure/revenue ratios to achieve fiscal consolidation. This room for manoeuvre was demonstrated in the post-Troika February 2011 General Election when political parties differed in proposals for expenditure/revenue ratios to achieve fiscal consolidation. Christian Democratic Fine Gael (FG) argued for a 3:1 expenditure/tax ratio, a centrist and pragmatic FF argued for $2: 1$, the social democratic Labour sought 50:50, while the centre left Sinn Fein (SF) focused on taxation. The mainstream parties competing for a place in government, FF, FG and Labour generally converged in approach to fiscal consolidation policies and all campaigned in favour of the EU Fiscal Compact Treaty in the 2011 Referendum (Dellepiane and Hardiman 2012, 10).

Electorally the crisis did provoke something of a double movement in the Irish electorate, the significant social dislocation created spontaneous moves by society to protect itself. This was expressed in the destruction of FF as the dominant force of Irish politics. However much has remained the same, while political cleavages are volatile and significant numbers of voters are 'undecided', there is no evidence of new political cleavages emerging (Kirby and Murphy 2011).

FG and Labour entered coalition government in March 2011, together they held 113 of 166 Dáil seats. Hacker's (2004) analysis of politics of the welfare state points to hidden and less visible ways in which current struggles take place. Domestic politicking amongst 
the coalition partners inspired 'a triple lock' which structured subsequent policy responses. The triple lock committed to protecting public sector pay, baseline adult social welfare rates and income tax levels. Rather than cutting rates, the focus was cuts in front line services and restricting eligibility and entitlement with negative but more hidden longer term impacts on welfare. Labour Party presence since 2011 may have contributed to the partial defence of some vital economic floors. A cut in the minimum wage effected by the 2010 government was restored by the incoming coalition, the coalition also reformed regressive 2010 Universal Social Charge (USC) thresholds and maintained a commitment to sectoral minimum wages in the face of attempts to abolish them. An initial internal coalition compromise of a 2:1 ratio in favour of cuts instead of tax increases softened to a 55:45 ratio in subsequent budgets. While the election of the Fine Gael/Labour coalition may have adjusted some aspects of fiscal consolidation, overall, with the Troika MOU as a roadmap, the new government continued the path dependence that locks Ireland into the liberal model. While partisan politics had some impact, both crisis governments were dominated by centre to centre right parties and were largely consistent, 'the profile of the Irish fiscal policy response to the economic crisis since 2008 has been quite consistently "orthodox ... the Irish government has displayed a steady commitment to the politics of fiscal retrenchment' (Dellepiane and Hardiman 2012, 9).

While various interests organised into political coalitions and developed transformative narrative positions (such as that of Plan B discussed earlier) and some independent candidates and socialist parties presented revolutionary frames, overall a neoliberal frame dominated electoral politics. Trade union interests, while weakened by the loss of the social partnership mechanism, along with civil society, retained some institutional and campaigning capacity to mitigate the scale of social impacts. Those most impacted by fiscal consolidation, young people under 25 and lone parents, are electorally weak, least able to build coalitions and have reduced political influence (Bonoli 2005). Relatively weak civil society coalitions tactically resorted to specific campaigns against cuts and achieved some minor climb-downs to welfare, health and education cuts. However these discreet successes contributed little to, and sometimes mitigated against, wider political coalition building and narrative building.

\section{Conclusion}

Is Ireland surviving without changing (Wickham 2013)? We conclude that unlike previous path shaping crises, this crisis has been characterised by path dependence and intensification. This time there has been no ontological or paradigm shift (Hall 1993). A powerful political and economic coalition proactively reshaped institutions to centralise power and continues to direct the nature of political discourse to maintain an already strong path dependence in the Irish economic and social model. The existing policy regime provides policy solutions. Those presenting alternatives appear uncertain about the definition of the core problem and potential policy solutions and there has been little contestation.

The analytical framework necessitated examination of competing ideologies and found an overwhelming narrative favouring fiscal consolidation and neoliberal policy. While there is some partisan variation overall domestic politics is consistent in how it shapes Irish budget decisions. The analysis highlights consistencies across political parties, an absence of extremities on left or right and no new political coalitions. Key institutional 
shifts show a centralisation of and narrowing of democratic representative and participative space that weakens non-elite political coalitions and their capacity to build alternative narratives. Despite significant social dislocation opposing political coalitions have been relatively weak and have neither sufficiently articulated nor won support for any alternative, nor been able to contest dominant narratives. The Troika presence can be interpreted as an important interest and institution that interacted and found convergence with domestic political business and media elites.

We conclude the interaction of ideas, interests and institutions not only maintained but intensified the neoliberal trajectory of the Irish political economy.

\section{Notes}

${ }^{1}$ Various features of paradigm change were present. Existing policy regime could not provide policy solutions. Those presenting alternatives appeared certain about the definition of the core problem and potential policy solutions and there was a significant period of contestation. New policy ideas both redefined the problem and potential solutions, a new policy regime was institutionalised and cognitively locked (Hall 1993).

${ }^{2}$ https://www.facebook.com/NoHouseholdTax and http://www.donegaldaily.com/2013/01/15/cant-paywont-pay-call-for-continuation-of-septic-tank-boycott.

\section{References}

Abowitz, K., and J. Hannish. 2006. Contemporary discourse on citizenship. Review of Educational Research 76 (4): $653-690$.

Barry, U., and P. Conroy. 2013. Ireland 2008-2012: Untold story of the crisis_-gender, equality and inequalities. In Women and austerity, ed. J. Rubbery and M. Karamessini, 186-206. London: Routledge.

Blyth, M. 2001. The transformation of the Swedish model: Economic ideas, distributional conflict and institutional change. World Politics 54 (1): 1-26.

Bonoli, G. 2005. The politics of the new social politics providing coverage against new social risks in mature welfare states. Policy and Politics 33: 431-449.

Callan, T., et al. 2013. The Great Recession, austerity and inequality: Evidence from Ireland. Intereconomics 48 (6): $335-338$.

Caritas. 2012. A study of the impact of the crisis and austerity on people with a special focus on Greece, Ireland, Italy, Portugal and Spain. Brussels: Caritas Europa.

Central Statistics Office (CSO). 2013. Survey on Income and Living Conditions: 2011 Results. Dublin: Stationery Office.

Coffey, T. 2011. A 10 point manifesto: Towards a second republic. Dublin: Dublin City Business Association.

Corcoran, M. P. 2004. The political preferences and value orientations of Irish journalists. Irish Journal of Sociology 13 (2): 23-42.

Cox, R. 1995. Critical political economy. In International political economy: Understanding global disorder, ed. B. Hettne, 31-45. London: Zed Books.

CPI. 2012. Repudiate the debt campaign leaflet. Dublin: Community Party of Ireland. http://www.nodebt.ie/

Dellepiane, S., and N. Hardiman. 2012. Governing the Irish economy: A triple crisis. In Irish governance in crisis, ed. N. Hardiman, 83-109. Manchester: Manchester University Press.

Doherty, M. 2011. It must have been love ... but it's over now: The crisis and collapse of social partnership in Ireland. Transfer: European Review of Labour and Research 17 (3): 371-387.

EAPN. 2013. Submission to Department of the Taoiseach on National Reform Programme. EAPN Europe 2020 Working Group. http://www.eapn.ie/eapn/submission-to-irelands-national-reform-programme-2013

Erne, R. 2013. Let's accept a smaller slice of a shrinking cake: The Irish Congress of Trade Unions and Irish public sector unions in crisis. Transfer: European Review of Labour and Research 19 (3): 1-40.

FitzGerald, J. 2014. Jobs for unemployed is key to reducing risk of poverty. Irish Times, January 16, Opinion. Gonzalez Pandiella, A. 2013. Getting Irish youth on track. Economics Department Working Papers No. 1101 (Eco/Wkp (2013) 93). Paris: OECD. 
Hacker, J. S. 2004. Privatizing risk without privatizing the welfare state: The hidden politics of social policy retrenchment in the United States. American Political Science Review 98 (2): 243-260.

Hall, P. A. 1993. Policy paradigms, social learning and the state. Comparative Politics 25 (3): 275-296.

Hall, P., and R. Taylor. 1996. Political science: The three new institutionalisms. Political Studies 44: 936-957. Hardiman, N., and A. Regan. 2012. The politics of austerity in Ireland. Intereconomics 48 (1): 9-13.

Harvey, B. 2013. Are we paying for that. Dublin: Advocacy initiative. http://www.advocacyinitiative.ie/ download/pdf/the_advocacy_initiative_are_we_paying_for_that_research_jan_2014.pdf (accessed June 18, 2014).

Hay, C. 2004. Ideas, interests and institutions in the comparative economy of great transformations. Review of International Political Economy 2 (1): 204-226.

Holland, L. 2012. Mauled by the Celtic Tiger: Human rights in Ireland's economic meltdown. Madrid: Centre for Economic and Social Rights.

Huber, E., and J. Stephens, eds. 2001. Development and crisis of the welfare state and policies in global markets. Chicago: Chicago University Press.

ICTU. 2008. Ten point plan for national solidarity. Dublin: ICTU.

Ireland. 1958. Programme for Economic Expansion. Dublin: Stationery Office.

Ireland. 1987. Programme for National Recovery. Dublin: Stationery Office.

Ireland First. 2011. A blueprint for Ireland's recovery. http://namawinelake.files.wordpress.com/2011/03/ irelandfirst.pdf (accessed June 18, 2014).

Kirby, K., and M. Murphy. 2011. Towards a second republic, Ireland after the Celtic Tiger. London: Pluto Press.

McCarthy, C. 2009. Report of the Special Group on Public Service Numbers and Expenditure Programmes. Dublin: Stationery Office.

Mercille, J. 2013. The role of the media in fiscal consolidation programmes: The case of Ireland. Cambridge Journal of Economics (December 11), DOI: 10.1093/cje/bet068.

Mulholland, J. 2010. The MacGill report: Reforming the Republic. Cloughjordan: Environmental Publications.

Murphy, M. P. 2013. Participating in popularising policy alternatives: A case study of Claiming our Future. In Politics, participation and power civil society and public policy in Ireland, ed. D. Ó Brionas and M. P. Murphy, 122-133. Dublin: Glasnevin Press.

NESC. 1987. A strategy for development growth, employment and fiscal balance. Dublin: Stationery Office.

NESC. 2009. Ireland's five part crisis: An integrated response. Report No. 118 Dublin: NESDO.

O’Toole, F. 2009. Ship of fools: How stupidity and corruption sank the Irish Celtic Tiger. Dublin: Penguin.

Parry, G. 1967. Political elites. London: Allen and Irwin.

Pierson, P. 1998. Irresistible forces, immovable objects post industrial welfare states confront permanent austerity. Journal of European Social Policy 5 (4): 539-560.

Polanyi, K. 2001. The great transformation: The political and economic origins of our time. Boston: Beacon Press. (Orig. pub. 1944.)

TASC. 2010. Mapping the golden circle. Dublin: TASC.

Tsebelis, G. 2002. Veto players: How political institutions work. Princeton, NJ: Russell Sage Foundation/ Princeton University Press.

Watson, D., and B. Maître. 2013. Social transfers and poverty alleviation in Ireland: An analysis of the CSO Survey on Income and Living Conditions 2004-2011. Social Inclusion Report No. 4. Dublin: DSP and ESRI.

Weymes, L. 2012. Fiscal consolidation does it deliver? Economics Letters Series, vol. 7. Dublin: Central Bank.

Wickham, J. 2013. Ireland surviving without changing? Panel session on National employment models, Europe speaks German now. IWPLMS 2013, September 12-14, Trinity College Dublin. 